\title{
Nonomuraea bangladeshensis sp. nov. and Nonomuraea coxensis sp. nov.
}

Correspondence

Yoko Takahashi

ytakaha@lisci.kitasato-u.ac.jp
The genus Nonomuraea was originally proposed by Zhang et al. (1998) as a member of the family Streptosporangiaceae which forms extensively branched substrate and aerial mycelia. On the basis of detailed phylogenetic analyses, the genus presently comprises 17 species and two subspecies (Gyobu \& Miyadoh, 2001; Quintana et al., 2003; Stackebrandt et al., 2001).

Abbreviations: DAP, diaminopimelic acid; ISP, International Streptomyces Project; OH-PE, hydroxyphosphatidylethanolamine; PE, phosphatidylethanolamine.

The GenBank/EMBL/DDBJ accession numbers for the 16S rRNA gene sequences of strains $5-10-10^{\top}$ and $5-38-42^{\top}$ are $A B 274966$ and AB274967 respectively.

Supplementary tables detailing cultural, physiological and chemotaxonomic characteristics, cellular fatty acid contents, 165 rRNA gene sequence similarities and DNA-DNA relatedness of strains 5-10-10 and $5-38-42^{\top}$ and related taxa are available with the online version of this paper.
In the course of an investigation into novel actinomycetes present in soil from the southern area of Bangladesh, we isolated strains $5-10-10^{\mathrm{T}}$ and $5-38-42^{\mathrm{T}}$ that showed morphological characteristics that are typical of the genus Nonomuraea. In this paper, the characterization and classification of these strains is described and two novel species of the genus Nonomuraea are proposed.

Strains $5-10-10^{\mathrm{T}}$ and $5-38-42^{\mathrm{T}}$ were isolated from sandy soil collected at a sea beach in Cox's Bazar, Bangladesh. The strains were isolated using the standard dilution plate method and grown on humic acid-vitamin agar (Hayakawa \& Nonomura, 1987) supplemented with cycloheximide $\left(50 \mathrm{mg} \mathrm{l}^{-1}\right)$, nystatin $\left(50 \mathrm{mg} \mathrm{l}^{-1}\right)$ and nalidixic acid $\left(20 \mathrm{mg} \mathrm{l}^{-1}\right)$. After 21 days of aerobic incubation at $30^{\circ} \mathrm{C}$, the strains were transferred and purified on yeast extractmalt extract agar (medium 2 of the International Streptomyces Project; ISP-2). The strains were maintained as working cultures on yeast-starch agar $(\mathrm{pH} 7.2)$ containing $\left(1^{-1}\right), \quad 15.0 \mathrm{~g}$ soluble starch, $4.0 \mathrm{~g}$ yeast extract, $0.5 \mathrm{~g}$ 
$\mathrm{K}_{2} \mathrm{HPO}_{4}, 0.5 \mathrm{~g} \mathrm{MgSO}_{4} .7 \mathrm{H}_{2} \mathrm{O}$ and $15.0 \mathrm{~g}$ agar. Nonomuraea fastidiosa JCM $3321^{\mathrm{T}}$ was used for comparative purposes in this study.

In order to determine cell morphology, strains $5-10-10^{\mathrm{T}}$ and $5-38-42^{\mathrm{T}}$ were grown on oatmeal (ISP-3) agar and yeast extract-malt extract (ISP-2) agar media at $30^{\circ} \mathrm{C}$ for 21 days and then observed by using light (S-2400; Hitachi) and scanning electron (JSM-5600; JEOL) microscopes. Samples for scanning electron microscopy were prepared as described by Ito et al. (1989) and Ara \& Kudo (2006).

The phenotypic properties of the two novel strains were examined using the following standard methods. For cultural characterization, the isolates were grown for 21 days at $30{ }^{\circ} \mathrm{C}$ on various agar media as described by Waksman (1950, 1961), Shirling \& Gottlieb (1966) and Asano \& Kawamoto (1986). The Colour Harmony Manual (Jacobson et al., 1958) was used to determine the names and designations of colony colours. The temperature range and $\mathrm{NaCl}$ tolerance for growth were determined on oatmeal agar. Utilization of carbohydrates as sole carbon sources was tested by using ISP-9 medium as a basal medium according to the modified method of Stevenson (1967). Production of melanoid pigments was examined using tyrosine agar (ISP-7).

For the analysis of chemotaxonomic characteristics, freezedried cells were obtained from cultures grown in yeastglucose or trypticase soy broth on a rotary shaker at $28^{\circ} \mathrm{C}$. The isomers of diaminopimelic acid (DAP) in the cell-wall peptidoglycan were determined by TLC as described by Staneck \& Roberts (1974). Reducing sugars from whole-cell hydrolysates were analysed by the paper chromatography method of Becker et al. (1965). The $N$-acyl group of the muramic acid in the peptidoglycan was determined according to the method of Uchida \& Aida (1984). Phospholipids in cells were extracted and identified according to the method of Minnikin et al. (1984). Methyl esters of cellular fatty acids were prepared and analysed by TechnoSuruga Co., Ltd. according to the instructions of the Microbial Identification System (MIDI) using GC (HP6890; Hewlett Packard) (Sasser, 1990). Isoprenoid quinones were extracted according to the method of Collins et al. $(1977,1984)$ and were analysed by HPLC (802-SC; Jasco) using a CAPCELL PAK C18 column (Shiseido) (Tamaoka et al., 1983). Preparation and detection of methyl esters of mycolic acids was carried out as described by Tomiyasu (1982).

The $\mathrm{G}+\mathrm{C}$ content of the DNA was determined using the HPLC method of Tamaoka \& Komagata (1984). An equimolar mixture of nucleotides for analysis of DNA base content (Yamasa Shoyu) was digested by bacterial alkaline phosphatase and used as the quantitative standard.

For DNA-DNA hybridization experiments, chromosomal DNA of strains $5-10-10^{\mathrm{T}}$ and $5-38-42^{\mathrm{T}}$ was isolated from biomass. Cells of the novel strains were freeze-dried and ground mechanically for preparation of chromosomal DNA as described by Raeder \& Broda (1985). DNA-DNA relatedness was measured fluorometrically using the microplate hybridization method devised by Ezaki et al. (1989). Hybridization was carried out overnight at $52{ }^{\circ} \mathrm{C}$.

Genomic DNA extraction, PCR-mediated amplification of the 16S rRNA gene and sequencing of the PCR products were carried out as described by Nakajima et al. (1999) and Ara \& Kudo (2006). The sequences were multiple-aligned with selected sequences obtained from the GenBank/EMBL/ DDBJ databases using the CLUSTAL_X program (Thompson et al., 1997). The alignment was manually verified and adjusted prior to construction of a phylogenetic tree. A phylogenetic tree was constructed by the neighbour-joining method (Saitou \& Nei, 1987) in CLUSTAL_X based on a comparison of 1262 nucleotides present in all of the strains as a result of elimination of gaps and ambiguous nucleotides from the sequences between positions 34 and 1491 (position numbering according to Escherichia coli). Thermopolyspora flexuosa DSM $43186^{T}$ was used as an outgroup. The confidence values of the branches of the phylogenetic tree were determined using bootstrap analyses based on 1000 resamplings (Felsenstein, 1985). The values for $16 \mathrm{~S}$ rRNA gene sequence similarity (\%) between Nonomuraea strains were calculated after pairwise alignment using CLUSTAL_X.

Analysis of cell morphology revealed that strains 5-10-10 ${ }^{\mathrm{T}}$ and $5-38-42^{\mathrm{T}}$ produced well-developed branched substrate and aerial mycelia and did not fragment into bacillary or coccoid elements. Spiral chains of strain $5-10-10^{\mathrm{T}}$ (covered by a smooth sheath) were composed of about 8-12 nonmotile spores that were borne directly, singly or in clusters, on aerial mycelia (Fig. 1a). For strain $5-38-42^{\mathrm{T}}$, spiral to hooked chains composed of 12-17 non-motile spores with a smooth surface were observed (Fig. 1b). A spore sheath was not observed for strain $5-38-42^{\mathrm{T}}$.

Strains $5-10-10^{\mathrm{T}}$ and $5-38-42^{\mathrm{T}}$ grew well on various inorganic and organic media and produced spore chains; the vegetative and aerial mycelia grew well on the agar media tested (see Supplementary Table S1 in IJSEM Online). The physiological and biochemical properties of strains 5-10-10 ${ }^{\mathrm{T}}$ and $5-38-42^{\mathrm{T}}$ are listed in Table 1 and in Supplementary Table S2 (available in IJSEM Online).

Chemotaxonomic analyses revealed that strains $5-10-10^{\mathrm{T}}$ and $5-38-42^{\mathrm{T}}$ exhibited characteristics that are typical for members of the genus Nonomuraea, such as the presence of meso-DAP and $\mathrm{N}$-acetyl muramic acid in the cell-wall peptidoglycan and the presence of madurose, galactose, glucose, mannose and ribose as whole-cell sugars (see Supplementary Tables S3 and S4 in IJSEM Online). The diagnostic phospholipids are phosphatidylethanolamine (PE) and hydroxyphosphatidylethanolamine (OH-PE). The major fatty acids for strain $5-10-10^{\mathrm{T}}$ are iso- $\mathrm{C}_{16: 0}$ $(26.4 \%)$, iso- $\mathrm{C}_{15: 0}(14.7 \%)$ and 10-methyl $\mathrm{C}_{17: 0}(10.5 \%)$. Small amounts of iso- $\mathrm{C}_{17: 0}(9.9 \%)$, iso- $\mathrm{C}_{16: 1}(7.3 \%), 10$ methyl $\mathrm{C}_{16: 0}(5.7 \%), \mathrm{C}_{17: 1} \omega 6 c(4.5 \%), \mathrm{C}_{17: 1} \omega 8 c(3.8 \%)$, $\mathrm{C}_{15: 0}(1.8 \%)$, summed feature $3\left(\mathrm{C}_{16: 1} \omega 7 c /\right.$ iso- $\left.\mathrm{C}_{15: 0} 2-\mathrm{OH}\right)$ $(1.8 \%)$, 10 -methyl $\mathrm{C}_{18: 0}(1.6 \%)$, anteiso- $\mathrm{C}_{17: 0}(1.6 \%)$, 

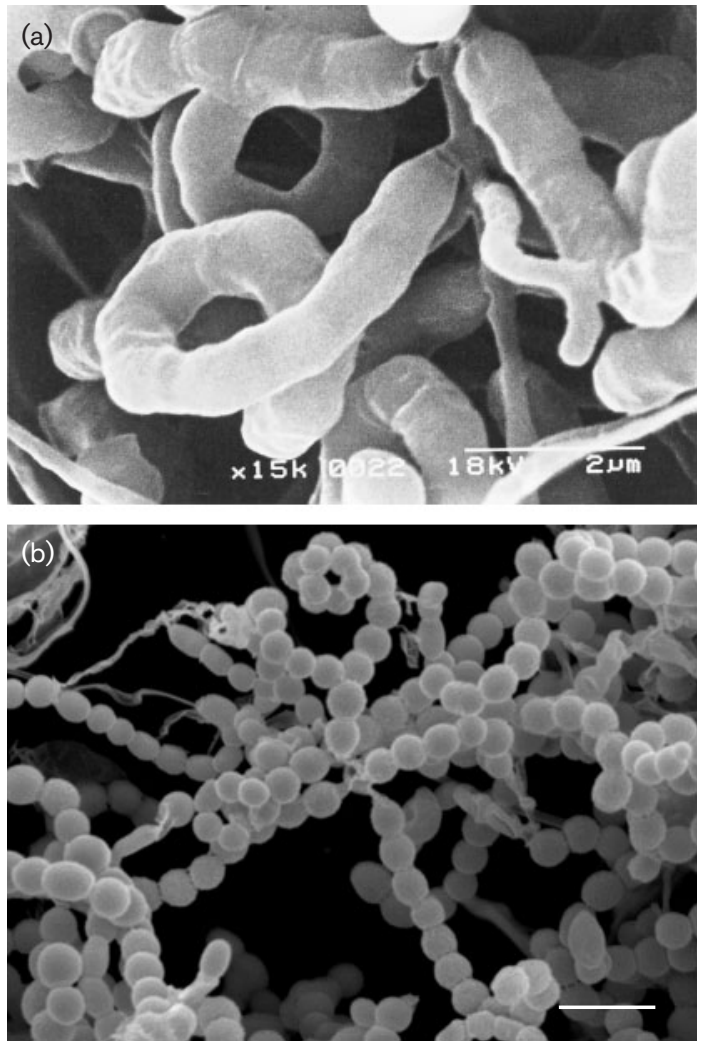

Fig. 1. Scanning electron micrographs of spiral spore chains covered with a sheath on aerial mycelia of Nonomuraea bangladeshensis sp. nov. $5-10-10^{\top}$ (a) and spiral spore chains of Nonomuraea coxensis sp. nov. $5-38-42^{\top}$ (b) grown on oatmeal agar at $30^{\circ} \mathrm{C}$ for 3 weeks. Bars, $2 \mu \mathrm{m}$.

iso- $\mathrm{C}_{14: 0}(1.5 \%), \mathrm{C}_{15: 0}(1.2 \%)$ and $\mathrm{C}_{18: 1} \omega 9 c(1.1 \%)$ are present in strain $5-10-10^{\mathrm{T}}$. For strain $5-38-42^{\mathrm{T}}$, the major fatty acids are $\mathrm{C}_{16: 0}(17.4 \%), \mathrm{C}_{17: 1} \omega 8 c(11.5 \%)$ and 10-methyl $\mathrm{C}_{17: 0}(8.4 \%)$, with smaller amounts of $\mathrm{C}_{15: 0}$ $(7.5 \%), \mathrm{C}_{17: 0}(6.7 \%)$, summed feature $3\left(\mathrm{C}_{16: 1} \omega 7 \mathrm{cl}\right.$ iso- $\left.\mathrm{C}_{15: 0} 2-\mathrm{OH}\right)(5.8 \%), \mathrm{C}_{14: 0}(4.6 \%), \mathrm{C}_{18: 1} \omega 9 c(4.5 \%)$, 10-methyl $\mathrm{C}_{16: 0}(3.3 \%), 10$-methyl $\mathrm{C}_{18: 0}(2.5 \%)$, anteiso$\mathrm{C}_{17: 0}(2.4 \%), \mathrm{C}_{17: 1} \omega 6 c(2.4 \%)$, iso- $\mathrm{C}_{15: 0}(2.2 \%)$, anteiso$\mathrm{C}_{15: 0}(2.0 \%), \mathrm{C}_{18: 0}(1.9 \%), 2-\mathrm{OH} \mathrm{C}_{16: 0}(1.9 \%)$ and $\mathrm{C}_{16: 1} \omega 9 c(1.3 \%)$ (Table 1 and Supplementary Table S4 in IJSEM Online). The major menaquinones observed were MK- $9\left(\mathrm{H}_{4}\right)$ for strain $5-10-10^{\mathrm{T}}$ and MK-9 $\left(\mathrm{H}_{6}\right)$ and MK-9 $\left(\mathrm{H}_{4}\right)$ for strain $5-38-42^{\mathrm{T}}$.

For the phylogenetic analysis, almost complete 16S rRNA gene sequences were determined for strains $5-10-10^{\mathrm{T}}$ and $5-38-42^{\mathrm{T}}$ consisting of 1513 and 1461 nucleotides, respectively. Phylogenetic analysis based on the 16S rRNA gene sequence indicated that strains $5-10-10^{\mathrm{T}}$ and $5-38-42^{\mathrm{T}}$ formed a coherent and monophyletic clade with N. fastidiosa that was supported by a bootstrap value of $57 \%$ (Fig. 2). Levels of gene sequence similarities between these strains ranged from $96.7 \%$ to $98.0 \%$ (see Supplementary Table S5 in IJSEM Online).
The DNA G + C contents of strains $5-10-10^{\mathrm{T}}$ and $5-38-42^{\mathrm{T}}$ were $72.7 \mathrm{~mol} \%$ and $72.3 \mathrm{~mol} \%$ respectively. DNA-DNA relatedness value between strains $5-10-10^{\mathrm{T}}$ and $5-38-42^{\mathrm{T}}$ was 57.7-58.2\%. DNA-DNA relatedness between the novel strains and the closely related type strain of $N$. fastidiosa ranged from 30.1 to $31.9 \%$ (mean value of four hybridizations) (see Supplementary Table S6 in IJSEM Online).

Strains $5-10-10^{\mathrm{T}}$ and $5-38-42^{\mathrm{T}}$ displayed morphological characteristics that are characteristic of other species of the genus Nonomuraea. In addition, based on their menaquinones and the predominant fatty acids in whole-cell methyl esters (Gyobu \& Miyadoh, 2001; Quintana et al., 2003; Kämpfer et al., 2005), strains 5-10-10 ${ }^{\mathrm{T}}$ and $5-38-42^{\mathrm{T}}$ should be placed in the genus Nonomuraea. The quinone system and fatty acid profiles also supported the affiliation of strains 5$10-10^{\mathrm{T}}$ and $5-38-42^{\mathrm{T}}$ as members of the genus Nonomuraea. Phylogenetic analysis based on 16S rRNA gene sequences showed that strains $5-10-10^{\mathrm{T}}$ and $5-38-42^{\mathrm{T}}$ clustered with $N$. fastidiosa in a group under the genus Nonomuraea.

Strains $5-10-10^{\mathrm{T}}$ and $5-38-42^{\mathrm{T}}$ could be distinguished from each other by morphological and cultural characteristics (see Fig. 1, Table 1 and Supplementary Table S1). Based on their menaquinones and the predominant fatty acids in whole-cell methyl esters (see Table 1 and Supplementary Tables S3 and S4), strains $5-10-10^{\mathrm{T}}$ and $5-38-42^{\mathrm{T}}$ represent two separate species in the genus Nonomuraea. The two novel isolates appeared to be relatively distantly related to other recognized representatives of the genus Nonomuraea. DNA-DNA hybridization is the standard criterion for the delineation of species with members of the same species having values of $\geqslant 70 \%$ DNA-DNA relatedness (Wayne et al., 1987). The DNA-DNA relatedness of strains 5-10$10^{\mathrm{T}}$ and $5-38-42^{\mathrm{T}}$ to the closely related type strain of $N$. fastidiosa was $<70 \%(30-32 \%)$ and the relatedness value between strains $5-10-10^{\mathrm{T}}$ and $5-38-42^{\mathrm{T}}$ was $58 \%$.

On the basis of cultural, morphological and physiological characteristics, biochemical reactions, chemotaxonomic characteristics and 16S rRNA gene sequences similarity, it is apparent that strains $5-10-10^{\mathrm{T}}$ and $5-38-42^{\mathrm{T}}$ represent separate species. It is proposed that the two isolates represent separate novel species of the genus Nonomuraea, Nonomuraea bangladeshensis sp. nov. (type strain, 5-10-10 $0^{\mathrm{T}}$ ) and Nonomuraea coxensis sp. nov. (type strain, $5-38-42^{\mathrm{T}}$ ). Characteristics that allow the differentiation of the two novel species from $N$. fastidiosa are listed in Table 1 .

\section{Description of Nonomuraea bangladeshensis sp. nov.}

Nonomuraea bangladeshensis (ban.gla.desh.en'sis. N.L. fem. adj. bangladeshensis pertaining to Bangladesh, from where the strain was isolated).

Forms a well-developed, branched substrate mycelium. Abundant aerial mycelium is present. Spore chains are spiral with one or two turns (8-12 spores). Sporangia are not 
Table 1. Differential physiological, morphological and chemotaxonomic characteristics of strains $5-10-10^{\top}, 5-38-42^{\top}$ and the phylogenetically related species, $N$. fastidiosa

Strains: 1, strain 5-10-10 ${ }^{\mathrm{T}}$; 2, strain 5-38-42 ${ }^{\mathrm{T}}$; 3, N. fastidiosa JCM $3321^{\mathrm{T}}$ (data are from Kämpfer et al., 2005, Kroppenstedt et al., 1990, Poschner et al., 1985 and Zhang et al., 1998). ND, Not determined; +, positive; -, negative; \pm , weakly positive; tr, trace; DPG, diphosphatidyglycerol; PE, phosphatidylethanolamine; PG, phosphatidyglycerol; PI, phosphatidylinositol; OH-PE, hydroxyphosphatidylethanolamine; GlcNU, phospholipids of unknown structure containing glucosamine. None of the strains produce melanin pigments.

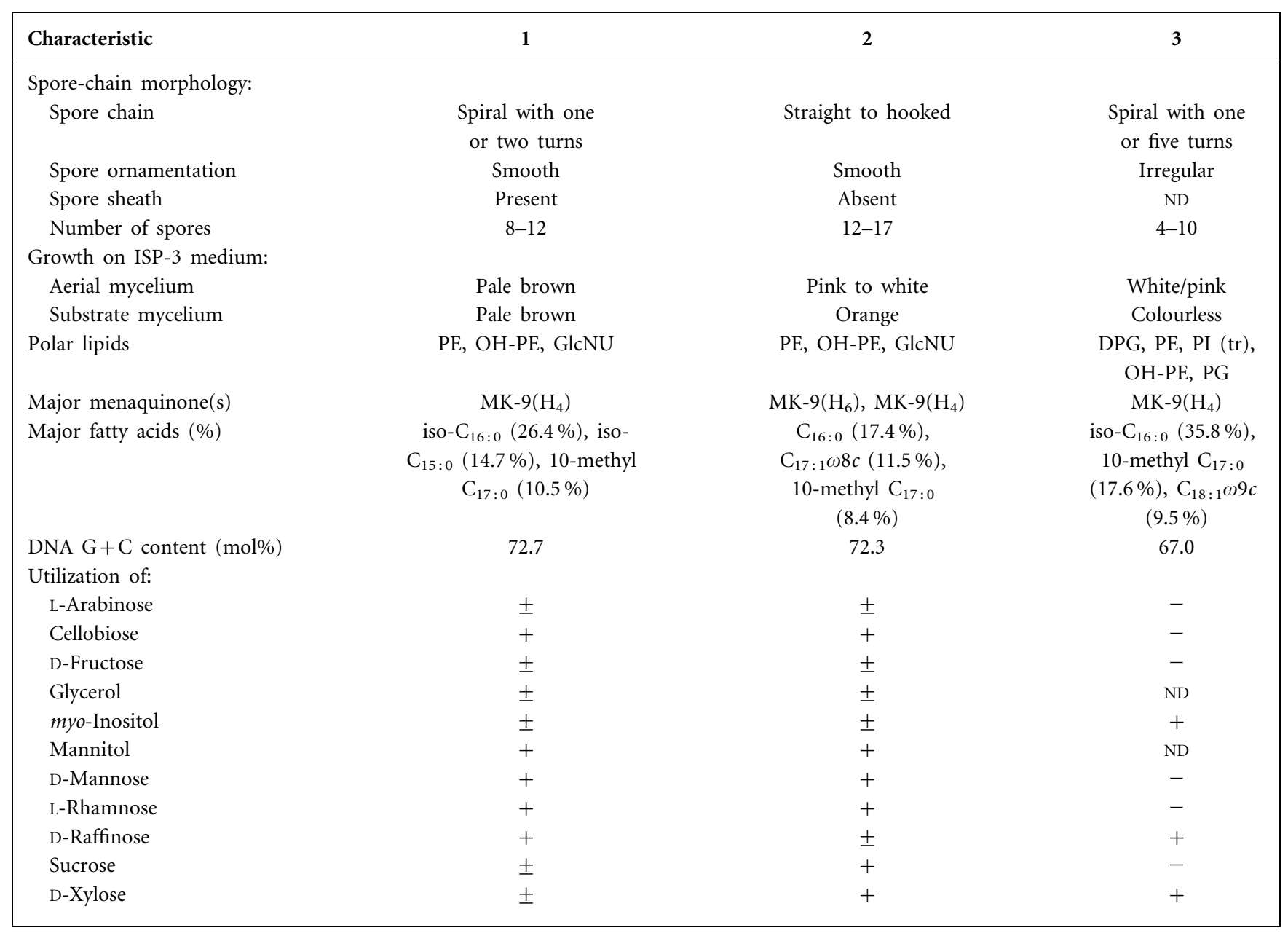

detected. Spores are spherical to cylindrical and the spore sheath surface is smooth. Good growth occurs on tyrosine agar (ISP-7), yeast extract-malt extract agar (ISP-2), oatmeal agar (ISP-3), Bennett's agar, glucose-yeast extract agar, Hickey-Tresner agar, Waksman agar, oatmeal-nitrate agar and Seino (yeast-starch) agar. Moderate growth is found on glycerol-asparagine agar, inorganic salts-starch agar (ISP-4), nutrient agar and water agar. Poor growth occurs with glucose-asparagine agar and sucrose-nitrate agar. The colour of the substrate mycelium is shell $(3 \mathrm{ca})$ to cinnamon brown (3lg) on various agar media. Pale brown aerial mycelium and sporulation occur on ISP-7 agar, ISP-2 agar, ISP-3 agar, water agar and oatmeal-nitrate agar media after 14 days incubation at $28^{\circ} \mathrm{C}$. A soluble pigment is not produced. Aerobic, Gram-positive and able to grow at $\mathrm{pH}$ 5.0-9.0. The temperature range for growth is between 15 and $45^{\circ} \mathrm{C}$. No production of melanoid pigments. No growth is observed at $5 \% \mathrm{NaCl}$. The diagnostic diamino acid isomer of the cell-wall peptidoglycan is meso-DAP. Madurose, galactose, glucose, mannose and ribose are present in whole-cell hydrolysates. The $\mathrm{N}$-acyl type of the muramic acid is acetyl. Mycolic acids are absent. The polar lipids include PE and OH-PE. Phosphatidylcholine is absent. The major menaquinone is MK-9 $\left(\mathrm{H}_{4}\right)$, with minor amounts of MK-9 $\left(\mathrm{H}_{6}\right)$, MK-9 $\left(\mathrm{H}_{2}\right)$ and MK-9 $\left(\mathrm{H}_{0}\right)$. Major fatty acids are iso- $\mathrm{C}_{16: 0}$ $(26.4 \%)$, iso- $\mathrm{C}_{15: 0}(14.7 \%)$ and 10 -methyl $\mathrm{C}_{17: 0}(10.5 \%)$. The $\mathrm{G}+\mathrm{C}$ content of the DNA is $72.7 \mathrm{~mol} \%$.

The type strain, strain $5-10-10^{\mathrm{T}}\left(=\right.$ MTCC $8089^{\mathrm{T}}=\mathrm{JCM}$ $13930^{\mathrm{T}}$ ), was isolated from sandy soil from Cox's Bazar, Bangladesh.

\section{Description of Nonomuraea coxensis sp. nov.}

Nonomuraea coxensis (cox.en'sis. N.L. fem. adj. coxensis pertaining to Cox's Bazar, Bangladesh, the origin of the soil from where the type strain was isolated). 


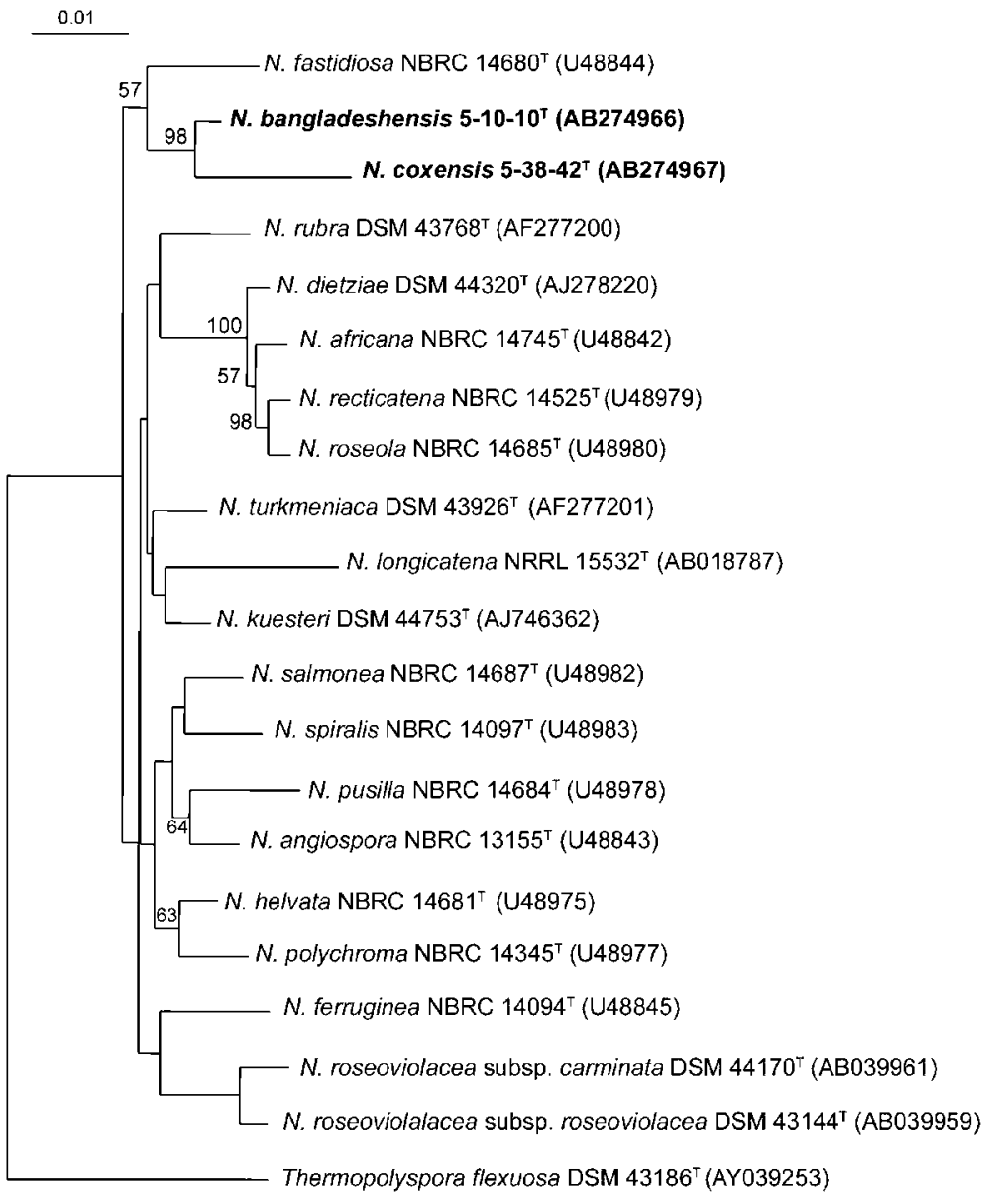

Fig. 2. Neighbour-joining tree (Saitou \& Nei, 1987) based on nearly complete $16 S$ rRNA gene sequences showing relationships between Nonomuraea bangladeshensis sp. nov. $5-10-10^{\top}$, Nonomuraea coxensis sp. nov. 5$38-42^{\top}$ and all recognized species of the genus Nonomuraea. Thermopolyspora flexuosa was used as an outgroup. Numbers at nodes indicate the levels of bootstrap support (\%) based on a neighbour-joining analysis of 1000 resampled datasets; only values above $40 \%$ are shown. Bar, 0.01 substitutions per site.
Forms a well-developed, branched substrate mycelium. Abundant aerial mycelium is present. Spore chains are spiral to hooked with 12-17 spores. Sporangia are not detected. Spores are spherical to oval and the spore surface is smooth. Good growth on yeast extract-malt extract agar (ISP-2), oatmeal agar (ISP-3), Bennett's agar, glucose-yeast extract agar, Hickey-Tresner agar, Waksman agar, 1/5 yeast-starch agar, oatmeal-nitrate agar and Seino (yeast-starch) agar. Moderate growth on tyrosine agar (ISP-7), inorganic saltsstarch agar (ISP-4) and nutrient agar; poor growth on water agar, glycerol-asparagine agar and glucose-asparagine agar. Substrate mycelium is light melon yellow (4ca) to apricot (orange-brown) (4ga) on various agar media. Pale pink to white aerial mycelium and sporulation occur on ISP-2 agar, ISP-3 agar, Bennett agar's, Hickey-Tresner agar and 1/5 yeast-starch agar media after 14 days incubation at $28^{\circ} \mathrm{C}$. A soluble pigment is not produced. Aerobic. Gram-positive. Growth occurs at $\mathrm{pH}$ 5.0-9.0. The temperature range for growth is between 15 and $45^{\circ} \mathrm{C}$. No production of melanoid pigments. No growth on $4 \% \mathrm{NaCl}$. The diagnostic diamino acid isomer of the cell-wall peptidoglycan is meso-DAP. Madurose, galactose, glucose, mannose and ribose are present in whole-cell hydrolysates. The $\mathrm{N}$-acyl type of muramic acid is acetyl. Mycolic acids are absent. The polar lipids include PE and OH-PE. Phosphatidylcholine is absent. The major menaquinones are MK- $9\left(\mathrm{H}_{6}\right)$ and MK- $9\left(\mathrm{H}_{4}\right)$. The fatty acid profile is characterized by the presence of significant amounts of $\mathrm{C}_{16: 0}(17.4 \%), \mathrm{C}_{17: 1} \omega 8 c(11.5 \%)$ and 10 -methyl $\mathrm{C}_{17: 0}(8.4 \%)$. The $\mathrm{G}+\mathrm{C}$ content of the DNA is $72.3 \mathrm{~mol} \%$.

The type strain, strain $5-38-42^{\mathrm{T}}\left(=\mathrm{MTCC} 8090^{\mathrm{T}}=\mathrm{JCM}\right.$ $\left.13931^{\mathrm{T}}\right)$, was isolated from sandy soil from Cox's Bazar, Bangladesh.

\section{Acknowledgements}

This work was financially supported by the Institute for Fermentation, Osaka (IFO) Japan and Japan Society for the Promotion of Science (JSPS). We wish to thank Ms Kurimi Morisaki, Ms Mayuko Yamada (Kitasato University, Japan) and Dr Mohammad Abdul Bakir (Japan Collection of Microorganisms, JCM, RIKEN, Japan) for technical support.

\section{References}

Ara, I. \& Kudo, T. (2006). Three novel species of the genus Catellatospora, Catellatospora chokoriensis sp. nov., Catellatospora coxensis sp. nov., and Catellatospora bangladeshensis sp. nov. and transfer of Catellatospora citrea subsp. methionotrophica Asano and Kawamoto 1988 to Catellatospora methionotrophica sp. nov., comb. nov. Int J Syst Evol Microbiol 56, 393-400. 
Asano, K. \& Kawamoto, I. (1986). Catellatospora, a new genus of the Actinomycetales. Int J Syst Bacteriol 36, 512-517.

Becker, B., Lechevalier, M. P. \& Lechevalier, H. A. (1965). Chemical composition of cell-wall preparations from strains of various formgenera of aerobic actinomycetes. Appl Microbiol 13, 236-243.

Collins, M. D., Pirouz, T., Goodfellow, M. \& Minnikin, D. E. (1977). Distribution of menaquinones in actinomycetes and corynebacteria. J Gen Microbiol 100, 221-230.

Collins, M. D., Faulkner, M. \& Keddie, R. M. (1984). Menaquinone composition of some spore forming actinomycetes. Syst Appl Microbiol 5, 20-29.

Ezaki, T., Hashimoto, Y. \& Yabuuchi, E. (1989). Fluorometric deoxyribonucleic acid-deoxyribonucleic acid hybridization in microdilution wells as an alternative to membrane filter hybridization in which radioisotopes are used to determine genetic relatedness among bacterial strains. Int J Syst Bacteriol 39, 224-229.

Felsenstein, J. (1985). Confidence limits on phylogenies: an approach using the bootstrap. Evolution 39, 783-791.

Gyobu, Y. \& Miyadoh, S. (2001). Proposal to transfer Actinomadura carminata to a new subspecies of the genus Nonomuraea as Nonomuraea roseoviolacea subsp. carminata comb. nov. Int J Syst Evol Microbiol 51, 881-889.

Hayakawa, M. \& Nonomura, H. (1987). Humic acid-vitamin agar, a new medium for selective isolation of soil actinomycetes. $J$ Ferment Technol 65, 501-509.

Ito, T., Kudo, T., Parenti, F. \& Seino, A. (1989). Amended description of the genus Kineosporia, based on chemotaxonomic and morphological studies. Int J Syst Bacteriol 39, 168-173.

Jacobson, E., Grauville, W. C. \& Fogs, C. E. (1958). Color Harmony Manual, 4th edn. Chicago: Container Corporation of America.

Kämpfer, P., Kroppenstedt, R. M. \& Grun-Wollny, I. (2005). Nonomuraea kuesteri sp. nov. Int J Syst Evol Microbiol 55, 847-851.

Kroppenstedt, R. M., Stackebrandt, E. \& Goodfellow, M. (1990). Taxonomic revision of the actinomycete genera Actinomadura and Microtetraspora. Syst Appl Microbiol 13, 148-160.

Minnikin, D. E., O'Donnell, A. G., Goodfellow, M., Alderson, G., Athalye, M., Schaal, A. \& Parlett, J. H. (1984). An integrated procedure for the extraction of bacterial isoprenoid quinones and polar lipids. J Microbiol Methods 2, 233-241.

Nakajima, Y., Kitpreechavanich, V., Suzuki, K. \& Kudo, T. (1999). Microbispora corallina sp. nov., a new species of the genus Microbispora isolated from Thai soil. Int J Syst Bacteriol 49, 1761-1767.

Poschner, J., Kroppenstedt, R. M., Fischer, A. \& Stackebrandt, E. (1985). DNA:DNA reassociation and chemotaxonomic studies on Actinomadura, Microbispora, Microtetraspora, Micropolyspora and Nocardiopsis. Syst Appl Microbiol 6, 264-270.
Quintana, E., Maldonado, L. \& Goodfellow, M. (2003). Nonomuraea terrinata sp. nov., a novel soil actinomycete. Antonie van Leeuwenhoek 84, 1-6.

Raeder, U. \& Broda, P. (1985). Rapid preparation of DNA from filamentous fungi. Lett Appl Microbiol 1, 17-20.

Saitou, N. \& Nei, M. (1987). The neighbor-joining method: a new method for reconstructing phylogenetic trees. Mol Biol Evol 4, 406-425.

Sasser, M. (1990). Identification of Bacteria by Gas Chromatography of Cellular Fatty Acids, MIDI Technical Note 101. Newark, DE: MIDI Inc.

Shirling, E. B. \& Gottlieb, D. (1966). Methods for characterization of Streptomyces species. Int J Syst Bacteriol 16, 313-340.

Stackebrandt, E., Wink, J., Steiner, U. \& Kroppenstedt, R. M. (2001). Nonomuraea dietzii sp. nov. Int J Syst Evol Microbiol 51, 1437-1441.

Staneck, J. L. \& Roberts, G. D. (1974). Simplified approach to identification of aerobic actinomycetes by thin-layer chromatography. Appl Microbiol 28, 226-231.

Stevenson, I. L. (1967). Utilization of aromatic hydrocarbons by Arthrobacter spp. Can J Microbiol 13, 205-211.

Tamaoka, J. \& Komagata, K. (1984). Determination of DNA base composition by reversed-phase high-performance liquid chromatography. FEMS Microbiol Lett 25, 125-128.

Tamaoka, J., Katayama-Fujimura, Y. \& Kuraishi, H. (1983). Analysis of bacterial menaquinone mixtures by high performance liquid chromatography. J Appl Bacteriol 54, 31-36.

Thompson, J. D., Gibson, T. J., Plewniak, F., Jeanmougin, F. \& Higgins, D. G. (1997). The CLUSTAL_X windows interface: flexible strategies for multiple sequence alignment aided by quality analysis tools. Nucleic Acids Res 25, 4876-4882.

Tomiyasu, I. (1982). Mycolic acid composition and thermally adaptative changes in Nocardia asteroides. J Bacteriol 151, 828-837.

Uchida, K. \& Aida, K. (1984). An improved method for the glycolate test for simple identification of the acyl type of bacterial cell walls. J Gen Appl Microbiol 30, 131-134.

Waksman, S. A. (1950). The Actinomycetes: Their Nature, Occurrence, Activities and Importance. Waltham, MA: Chronica Botanica.

Waksman, S. A. (1961). Classification, identification, and description of genera and species. In The Actinomycetes, vol. 2. Baltimore: Williams \& Wilkins.

Wayne, L. G., Brenner, D. J., Colwell, R. R., Grimont, P. A. D., Kandler, O., Krichevsky, M. I., Moore, L. H., Moore, W. E. C., Murray, R. G. E. \& other authors (1987). International Committee on Systematic Bacteriology. Report of the ad hoc committee on reconciliation of approaches to bacterial systematics. Int $J$ Syst Bacteriol 37, 463-464.

Zhang, Z., Wang, Y. \& Ruan, J. (1998). Reclassification of Thermomonospora and Microtetraspora. Int J Syst Bacteriol 48, 411-422. 